\title{
Evaluation of land resource utilisation of Dankotuwa Divisional Secretariat Division, Puttlam District using GIS techniques
}

\author{
By
}

\author{
D. M. D. P. K. Panagoda
}

This dissertation is submitted in partial fulfillment of the Degree of Master of Science (Forestry and Environmental Management)

Department of Forestry and Environmental Science

Faculty of Graduate Studies

University of Sri Jayawardenapura

Nugegoda, Sri Lanka

$30^{\text {th }}$ November 2015 


\section{DECLARATION}

The work described in this dissertation was carried out by under supervision of Dr. S.M.C.U.P. Subasinghe, Senior Lecturer, Department of Forestry and Environment Science of Sri Jayawardenapura, Sri Lanka.

I declare that this is my own work and this dissertation does not incorporate without acknowledgment any material previously submitted for a Degree or Diploma in any other University or institute of higher learning and to the best of my knowledge and belief it does not contain any material previously published or written by another person except where the acknowledgment is made in the text.

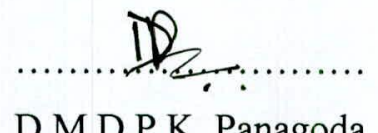

D.M.D.P.K. Panagoda

Date: 30.11 . 9015 


\section{SUPERVISOR CERTIFICATION}

I certify that the above candidate has carried out research for the M.Sc Dissertation under my supervision and is now approved for submission.

Signature:

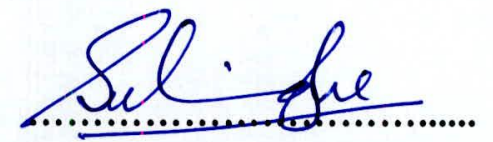

Dr. S.M.C.U.P. Subasinghe,

Senior Lecturer,

Department of Forestry and Environmental Science,

University of Sri Jayawardenapura,

Nugegoda,

Sri Lanka.

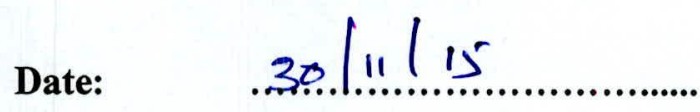




\section{TABLE OF CONTENTS}

List of tables ...................................................................

List of figure .....................................................................

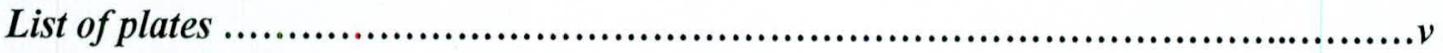

Abbreviations .................................................................

Acknowledgement ............................................................

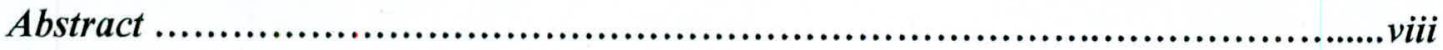

CHAPTER 01: INTRODUCTION.................................................

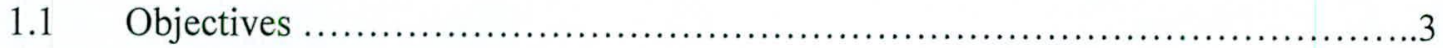

1.1.1 Specific objectives .................................................

CHAPTER 02: LITRUTURE REVIEW .........................................

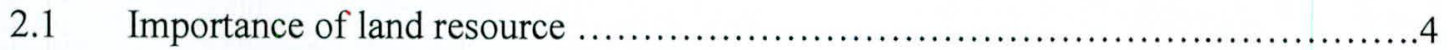

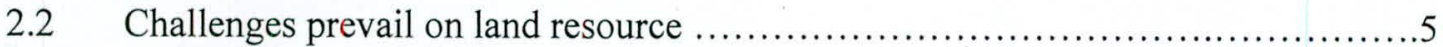

2.3 Integrated panning for sustainable management of land resource ..................

2.4 Land utilisation patterns in Sri Lanka and its impacts ........................

2.4.1 Land degradation in Sri Lanka ............................................................. 9

2.4.2 Causes of land degradation in Sri Lanka ...............................10

2.5 Policy, strategy and legislative provisions for land management

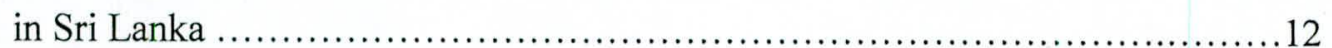

2.5.1 Institutional framework of land management in Sri Lanka ................13

2.6 Land use pattern and land related issues in North Western Province

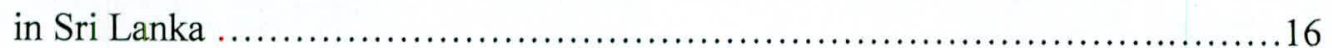

2.7 Application of Geographical Information System in land management ............18

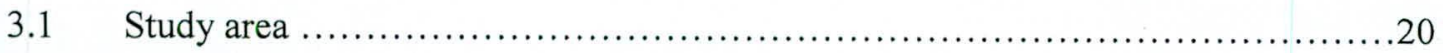

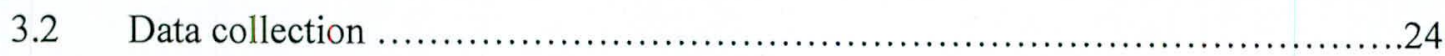




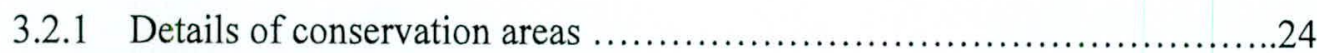

3.2.2 Details of underutilisation ......................................24

3.2.3 Details of misuse ..............................................25

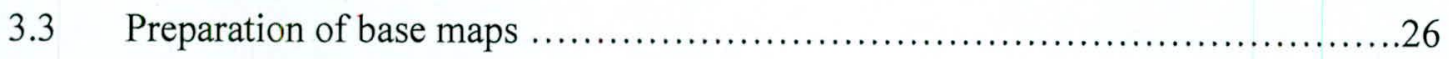

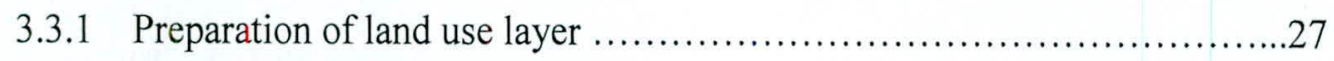

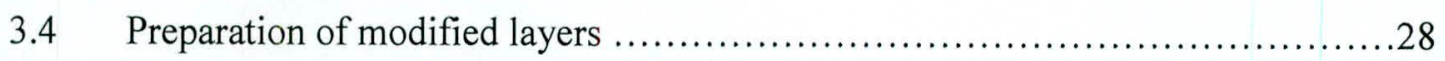

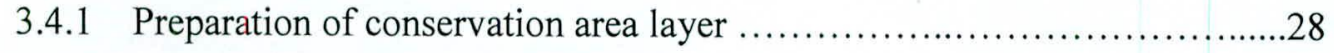

3.4.2 Preparation of underutilised land layer ................................28

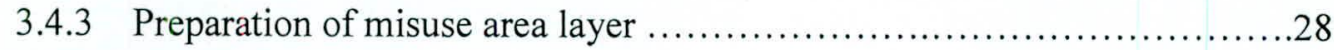

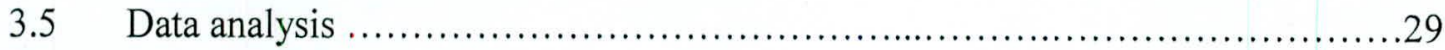

CHAPTER 04: RESULTS ..........................................................

4.1 Land use types of the study area ......................................... 30

4.2 Land related issues prevail in Dankotuwa Divisional Secretariat Division ..........33

4.2.1 Issues of the conservation areas ..........................................

4.2.2 Underutilised areas .................................................

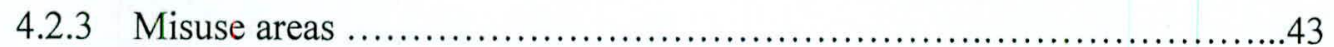

4.3 Reasons of land issues identified in this study ..............................46

4.3.1 Reasons for the issues of conservation areas at present ..................46

4.3.2 Reasons for the underutilised areas ..................................46

4.3.3 Reasons for misusing the identified areas .............................54

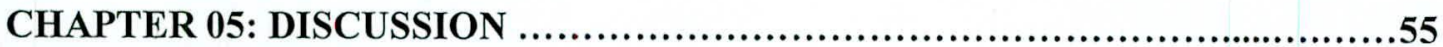

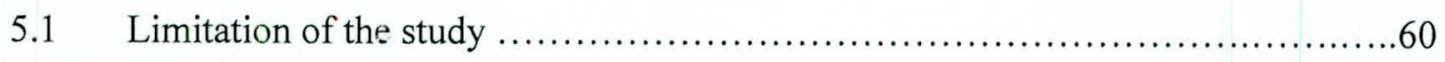

CHAPTER 06: CONCLUTION .............................................61

CHAPTER 07: RECOMMONDATIONS .........................................63

REFERNCES

ANNEXES 


\section{LIST OF TABLES}

Table 2.1: $\quad$ Land use information for North-Western Province ....................... 16

Table 3.1: Grama Niladhari Division numbers and names ...........................23

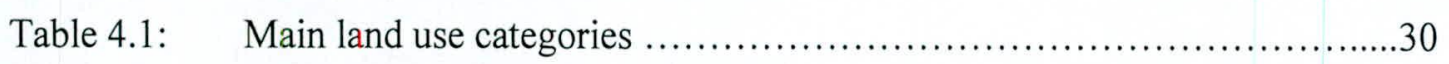

Table 4.2: Land utilisation pattern of Dankotuwa DSD ............................. 30

Table 4.3: Conservation areas in Dankotuwa Divisional Secretariat Division ...........33

Table 4.4: Issues prevail in the conservation areas of the Dankotuwa DSD............34

Table 4.5: Underutilised coconut lands according to the land size ..................... 36

Table 4.6: Underutilised paddy lands according to the land size ...................... 38

Table 4.7: Extent of above one-acre homegardens identified in the

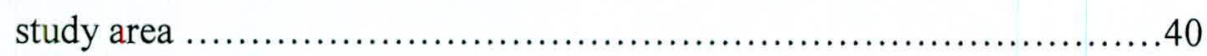

Table 4.8: Underutilised homegardens according to the land cover ..................41

Table 4.9: Misuse activities and extents in Dankotuwa DSD ..........................44

Table 4.10: Misuse lands according to the land cover and size ......................44

Table 4.11: Reasons for the issues of conservation areas .........................46

Table 4.12: Reasons for the underutilised coconut lands ...........................47

Table 4.13: Reasons for the underutilised paddy lands ............................49

Table 4.14: Reasons for the partly utilised homegardens ...........................51

Table 4.15: Reasons for the non-utilised homegardens .............................51

Table 4.16: Reasons for the misusing areas identified in the study area ................54 


\section{LIST OF FIGURES}

Figure 2.1: Symptoms, problems of land and causes ..........................6

Figure 2.2: Link between local level, provincial level and national level

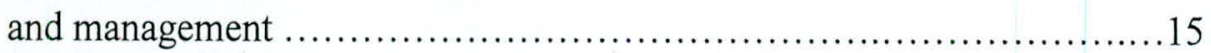

Figure 3.1: Dankotuwa Divisional Secretariat Division ..........................21

Figure 3.2: Grama Niladhari Divisions of Dankotuwa DSD ..........................22

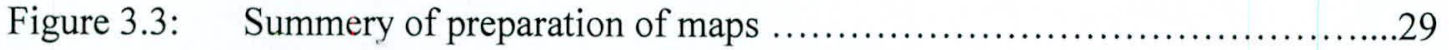

Figure 4.1: $\quad$ Main land use categories of Dankotuwa DSD ............................. 31

Figure 4.2: Land utilisation pattern of Dankotuwa DSD .............................. 32

Figure 4.3: Dankotuwa DSD map depicts the issues of the conservation areas ..........35

Figure 4.4: Underutilised coconut lands in the Dankotuwa DSD....................... 37

Figure 4.5: Underutilised coconut paddy in the Dankotuwa DSD ...................... 39

Figure 4.6: Type of homegarden in the study area ..............................42

Figure 4.7: Misuse areas in the Dankotuwa DSD ...............................45

Figure 4.8: Factors of underutilised coconut lands and extent .......................47

Figure 4.9: Reasons for the underutilisation coconut lands in the Dankotuwa DSD .......................................................... 48

Figure 4.10: Factors of underutilised paddy lands and extent........................49

Figure 4.11: Reasons for the underutilsation of paddy lands in Dankotuwa DSD .......50

Figure 4.12: The reasons for partly utilised homegarden with land cover ...............52

Figure 4.13: The reasons for partly utilised homegarden with land cover ...............52

Figure 4.14: Reasons for underutilised homegarden with Dankotuwa DSD...............53 


\section{LIST OF PLATES}

Plate 4.1: $\quad$ Clay mining area in Ma Oya $100 \mathrm{~m}$ buffer zone

(Jankurawela GND) .......................................... 34

Plate 4.2: $\quad$ Spread of invasive species in Mellawa wewa

(Mellawa GND) ................................................

Plate 4.3: Underutilised coconut land in Ihala bujjampola GND .................... 36

Plate 4.4: $\quad$ Underutilised paddy land in North haldaduwana GND .....................38

Plate 4.5: $\quad$ Fully utilised homegarden with minor crops in Thulawala GND ...........40

Plate 4.6: Partly utilised homegarden with coconut in Meda gonavila GND ...........41

Plate 4.7: Non-utilised homegarden in Hundirapola GND ........................... 41

Plate 4.8: $\quad$ Extraction of clay mining in large scale (Metikotuwa GND) ...............43

Plate 4.9: Gravel mining area in Thulawala ....................................43

Plate 4.10: Land filling area in Godella GND ...................................44

Plate 4.11: Waste disposal area in South dankotuwa GND .........................44 


\section{ABBREVIATIONS}

$\begin{array}{lll}\text { CRI } & - & \text { Coconut Research Institution } \\ \text { DSD } & - & \text { Divisional Secretariat Division } \\ \text { GCP } & - & \text { Ground Control Point } \\ \text { GDP } & - & \text { Gross Domestic Produces } \\ \text { GIS } & - & \text { Geographical Information System } \\ \text { GND } & - & \text { Grama Niladhari Division } \\ \text { ha } & - & \text { Hectare } \\ \text { NWP } & - & \text { North Western Province } \\ \text { UTM } & - & \text { Universal Transverse Mercator }\end{array}$




\section{ACKNOWLEDGEMENTS}

I extend my sincere gratitude to my supervisor Dr. S.M.C.U.P.Subasinghe, Senior Lecturer of the Department of Forestry and Environmental Science, University of Sri Jayawardenapura, for his valuable guidance and supervision throughout the study.

I would like to acknowledge Dr. Priyan Perera, Course coordinator, Msc programme, for providing necessary information and the support given.

I would like to express my deepest gratitude to Mr. W.P. Senadeenra, Divisional Secretary, Dankotuwa, Grama Niladhari Officers, and Economic Development Officers attached in Dankotuwa Divisional Secretariat Office, for arranging field visits and the assistance given.

I gratefully acknowledge the members of community base organisations in Dankotuwa and villages for helping me to carry out field work.

I am grateful to Mr. H.P. Sisira, Assistant Director (Agriculture Economist), and Mr. Jayalal Dassanayake, Land Use Planning Officer, Department of Land Use Policy Planning for his valuable guidance and advice throughout the study.

Next, I greatly acknowledge Director, Coconut Research Institution, Lunuwila, Director, Coconut Cultivation Board in Marawila, Divisional Officer in Agrarian Services Center, Haldaduwana, Agricultural Officers, and Coconut Development Officers for their assistance provided in data collection and the support given.

I gratefully acknowledge the officers in Provincial Secretariat Office in Kurunegala, District Secretariat in Puttlam, for providing necessary information in data collection.

I would like express my heartfelt gratitude to Mr. S.C. Walpita for his honest support throughout the Msc programme.

Last but not the least, I would like express my heartiest gratitude to my husband and daughter for their boundless support given to me throughout this study. 


\begin{abstract}
D.M.D.P.K. Panagoda (2015), Evaluation of land resource utilisation of Dankotuwa Divisional Secretariat Division, Puttlam District using GIS techniques. MSc Dissertation, Department of Forestry and Environmental Science, Faculty of Graduate Studies, University of Sri Jayawardenepura, Sri Lanka.
\end{abstract}

\begin{abstract}
Land resource is limited and finite, hence an important economic asset as a source of livelihood. Due to complex reason, management of land resource has become one of most critical problems prevail at present. Land degradation is significant in Sri Lanka due to a variety of unwarranted human activities such as mining, encroachment, deforestation, solid waste disposal, un-treated effluent discharge etc. Therefore, it is necessary to utilise it in the best possible way ensuring the minimum damage.

In order to identify the micro-level planning of land resources, the present study attempted to map the land use and to identify the land related issues in Dankotuwa Divisional Secretariat Division (DSD) using GIS techniques.

Survey Department map sheet 52 of Kochchikade (Scale 1:50,000) was digitised after georeferencing in ArcGIS 10.1 software to draw the DSD boundary, roads, irrigation cannels, main water bodies and other important landmarks. It was then superimposed with the Google Earth satellite image to identify the existing land use patterns of the study area. Those details of the base map were verified by field visits.
\end{abstract}

Seven land use categories, viz., agriculture, barren, built-up, forest, marsh, scrub and water body were identified in map analysis as main land use classes. The agriculture layer was further modified to depict coconut, paddy, rubber, homegardens and other uses.

Both man-made activities and natural causes were considered to identified the issues of the protected areas. Underutilisation and alternative uses such as land filling, gravel mining and clay mining were considered as misuses in coconut and paddy lands. A questionnaire survey was conducted with the relevant officers of the government institutes and community based organisations of Dankotuwa DSD to obtain necessary data. In addition, ground surveys were conducted to identify the land related issues. The identified land related issues were then marked with respective maps.

Among these agricultural lands, 3518.49 ha were used as homegardens, 2280.93 ha was used as coconut and 1210.98 ha and 112.31 ha were used as paddy and other plantation respectively. Only natural forest identified in the Dankotuwa DSD was Kalumukalana of 33.75 ha in extent.

The results of the present study further indicated that the highest land use allocation was given for the agriculture and lowest was given for scrublands. Out of the total land extent (7890.5 ha) of Dankotuwa DSD, 8.62\% had land related issues. Underutilised coconut and paddy was contained 400.16 ha, and out of the selected 94 homegardens, 66 was partly utilised and 17 was non-utilised. Clay mining for bricks and tile industries is a significant problem affecting negatively on the environment. Clay mining has also become a considerable issue in the Ma Oya reservation causing severe damage to the river bank. Clay and gravel mining and land filling were the main misuses and the growth of construction industry has caused an increased demand for these extractions. Land filling for constrictions is the second major misuse found in the study area. The spread of invasive species reducing the water quality in the small irrigation tanks was a natural cause of degradation. Finally, the study recommends actions to be taken to minimise the land degradation enhancing the sustainable use. 


\section{CHAPTER 01: INTRODUCTOIN}

Human wealth depends on the consumption of natural resources, including materials, energy and land. Continued increase in resource use and the related environmental impacts cause negative affects leading to ecological disasters. Therefore, the sustainable use and management of natural resources have come into focus and have been the subject of many policy discussions over many decades (EEA, 2003).

Land is an essential natural resource, both for survival and prosperity of humanity and for the maintenance of all terrestrial ecosystems. The limits on land resource is finite and increased demand and/or pressure on land made the decline of crop production, degradation of land quality and quantity (FAO, 2009).

The change of land use has become a serious issue in the recent years. Improper land use can lead to various human, biological and environmental problems. The Forth Global Environment Outlook published by the United Nations Environmental Programme in 2007 highlighted the increase of human population, economic development and development of global market was leads to the land use changes and cause for resource depletion and ecosystem degradation (UNEP, 2007). Therefore, sustainable management of land resource is critical to maintain other natural resources and ecosystem functions.

The livelihood of Sri Lanka is closely related with land and related of ecosystems. Therefore, natural resource management has become a focal point of the economic, social and cultural development process of Sri Lanka. The land resource of Sri Lanka is presently considered comparatively healthy, nevertheless it is being severely threatened because of the demands being placed by a rapidly increasing population (MENR, 2002). The country faces a number of land related issues such as increase of improper land use practices, increase of unproductive areas. During the last few decades natural disasters have been on the increase because of improper land uses in Sri Lanka. Especially, human settlement and cultivation of annual crops on steep slops lands have resulted in rapid soil erosion, landslides and the silting of rivers, waterways and reservoirs (National Land Use Policy, 2004). 
Underutilisation of lands is also another issue that has to be properly addressed to increase the productivity. Abandonment and underutilisation is commonly seen in the agricultural sector. Abandonment occurs mainly due to development of socio economic and environmental conditions. With the increase of population pressure on land alternative uses such as land filling, extraction of sand, clay, gem and gravel are common in the agricultural lands for meeting human needs (Kendaragama et. al.,2000).

The Government of Sri Lanka formulated many policy initiatives, strategies and legislations to deal with issues pertaining to land management. In addition, a large numbers of state and private agencies are involved in the management of state and private lands. However, despite these initiatives land related issues continue at a large scale. On the other hand, political pressures and/or influences affect the land resource base directly or indirectly leading to critical environmental issues (MOFE, 2000). Nevertheless, the Government and international agencies, over the decades, provided financial support through various strategic plans to overcome this miserable situation. Although there are very few successful stories, a majority of these actions were failures primarily due to unplanned follow-up mechanisms, weak involvement of community based organisations, mismanagement, poor coordination of inter-governmental organisation in different sectors and competing and conflicting approaches to the problem concerned (MOFE, 2000). While recognising weaknesses and failures of the majority of the past events, and also foreseen future risks, it has been identified and recommended to adopt increased collaboration of stakeholders in the process of land resource management for sustainable livelihood (Berugoda, 1998).

In Sri Lanka, many macro-level projects have been implemented to create balance between land and human. However, it is also necessary to initiate micro-level programmes especially in rural areas because, the dependence the land is high in rural areas. In addition, better coordination between responsible institutes can be implemented in successful manner with micro level planning.

Therefore, the present study attempted to evaluate the sustainability of land resource utilisation of Dankotuwa Divisional Secretariat Division of Puttlam District by using Geographic Information Systems. In addition to that, an attempt was made to form a 
sustainable land resource utilisation plan to improve the quality of land use in Dankotuwa Divisional Secretariat Division.

The outcomes of this study will provide essential information regarding the land related issues and sustainable utilisation of land resources at a micro-level. It will further assist for land use planners and decision makers to utilise natural resources in sustainable manner.

\subsection{Objectives}

The main objective of this study was to evaluate of land resource utilisation of Dankotuwa Divisional Secretariat Division in Puttlam District.

\subsubsection{Specific objectives}

i. Identification of the present land use pattern of the Dankotuwa Divisional Secretariat Division of Puttlam District by using Geographical Information System.

ii. Identification and mapping of land related issues of the Dankotuwa Divisional Secretariat Division.

iii. Formulation of recommendations for the utilisation of land resource reducing land related issues. 


\section{CHAPTER 02: LITERATURE REVIEW}

\subsection{Importance of land resource}

Earth is unique to the solar system and it has many favorable conditions suitable for the growth and development of human, animals and plants. Natural resources play major role in human survival and satisfaction. Human wealth is based on the use and consumption of these natural resources including materials, energy and land. These resources are continuously use for human needs and therefore it is important to be aware of current use of the natural resources. All these resources are finite due to their limited supply and therefore it is need to utilise these in the best possible way, ensuring maximum benefits with minimum problems. Over the twenty years, major international conferences such as the United Nations Conference on Environment and Development (UNCED) in Rio de Janeiro, Brazil (1992) and the World Food Summit in Rome, Italy (1996) have clearly established the need to alleviate poverty, ensure food security and maintain natural resources for future generations. Therefore, natural resource management has become a focal point of the economic, social and cultural development process of the world (FAO,1996).

Land is an essential natural resource, both for the survival and prosperity of humanity, and for the maintenance of all terrestrial ecosystems. According to the FAO (1996), land is defined as,

"delineable area of the earth's terrestrial surface, encompassing all attributes of the biosphere immediately above or below this surface, including those of the near surface climate, the soil and terrain forms, the surface hydrology (including shallow lakes, rivers, marshes and swamps), the near surface sedimentary layers and associated groundwater and geohydrological reserve, the plant and animal populations, the human settlement pattern and physical results of past and present human activity (terracing, water storage or drainage structures, roads, building etc.)".

Land posseses only $30 \%$ of the earth surface and of this space, only fraction is habitable by humans. This $30 \%$ of land is occupied by $90 \%$ human population. The other $70 \%$ is made of vast deserts, dense forests and rugged mountains (Socio economic data, 2013). 